\title{
The Vulnerability of Male Gender and State Response in the Female Labor Protection Policy: A Case Study of New Industrial Communities in Purbalingga Regency
}

\section{Tobirin}

\begin{abstract}
This article discusses the role dominance female gender in the public domain compared to male. So far, gender relations always place female in subordinate conditions and in one condition, male dominate. Minimal gender relations are assessed from the opposite condition. Male is subordinated and female dominate, where male is more vulnerable than female. The purpose of this article is to analyze the vulnerability of male in the labor family in the state's response to female labor protection policies. The research method used is a mixed method, an approach that combines quantitative methods with survey and qualitative approaches with in-depth interviews. The results of this study indicate new gender relations in the family of workers. Female workers become the main breadwinner, gain trust in financial institutions, and develop economic networks through the plasma industry by empowering the surrounding community and accessibility to work. Meanwhile, male is in vulnerable positions with limited employment opportunities, lower income, and feel ashamed of domestic roles. Besides, state response in public policy is less favorable to male in employment; countries in responding to the implications of the emergence of new gender relations still assume female domination in the domestic sphere. In view of this, the local government of Purbalingga Regency should do the following; a) develop family care policies by assuming new female gender roles that are more dominant in the public sphere. $b$ ) Build awareness of the advancement of female as a positive thing in realizing a harmonious family by the role of new males who have high gender awareness.
\end{abstract}

\section{Keywords:}

dominance; industrial community; new gender relations; vulnerability

\section{Introduction}

Previous research in examining the role of gender in female workers in Indonesia still places the old paradigm. It is stated that male dominates and female is in subordination position. Besides, the dynamics in gender relations places females where they are more vulnerable than male. Research on gender relations has not been widely studied with the opposite conditions, namely males are more vulnerable than females. Similarly, the dominance of female in gender relations in families with lower economic levels has not been a concern in gender studies. This condition is possible due to global developments and changes. One of them is that females have increased $71.1 \%$ in work participation. In addition, the average income continues to increase, and more females are now entering managerial work with high salary standards

\footnotetext{
- Department of Public Administration, Universitas Jenderal Soedirman

Email: tobirin@unsoed.ac.id
} 
(Vitali \& Mendola 2014). This is the gap and opportunity to examine gender issues that focus on male vulnerability and the dominance of female in gender relations that have novel values.

This article examines the vulnerability of male in the economy and social, as well as the dominance of female in gender relations in the industrial labor family. Vulnerability is associated with an individual's ability to protect own self and the ability to cope with stress and unpleasant conditions. The economic vulnerability is related to poverty, income, employment, and asset acquisition. Meanwhile, the social vulnerability is related to social relations, education, health, family leadership, politics, law, and institutions (Habibi \& Buchori, 2013).

The vulnerability and powerlessness of male in socio-economic conditions in developed countries in the Rosin study (2012) is explained in a book entitled the end of male and the rise of female. This book examines changes in the role of female not only in romance and in family, but also examines the growth of new matriarchies in middle-class female. They influence social change, where females are able to build new economies in times of crisis with their social intelligence. In addition, females have equal opportunities in education, even more than male in achieving higher education. Females have also taken on the role of top managers in well-known companies, as well as the ability of Asian female to take over the world with a wider role. In conclusion, females are able to control the world and succeed in adapting to the new economic realities of the $21^{\text {st }}$ century, while males experience a different fate as generally as the main role taker in the public sphere. Males have not been able to adapt to the changing environment in a sluggish economy manufacturing industry.

The study reinforces the importance of gender studies that examine the vulnerability of socio-economic male and the dominance of female in gender relations. Gender studies that focus on male vulnerability, in Indonesia, are studies that are still not a concern for gender researchers. This research at least provides a new perspective in reviewing female workers. The gender roles of male in social construction are considered unlucky in people's lives and marginalized in their gender roles. The social and economic vulnerability of male is not regarded as a reproduction of masculinity to explain its helplessness, but in an effort to understand and analyze gender dynamics that continue to develop and change in accordance with global demands.

Along with changes and global conditions that are experiencing a crisis, male hegemony slowly changes. The role of female gender appears different from the new face of female who have an identity with mobility and professional success in the reality of their position. Female are subordinated and discriminated in carrying out their gender roles. The article from Singh (2014) on the status of female in today's community, mentions the factors that determine the increase in the status of female in modern community. They are analyzed in the aspects of regulation, education, economy and employment, political awareness and participation, and awareness of their rights. In the field of education, they became the dominant factor in increasing the role of female. In this field, female represented three quarters of $75.6 \%$ from 493,440 employees with tertiary education. Female represented a quarter of $25.5 \%$ of employees with tertiary education, where female are more than half $56.5 \%$ of female teachers in public schools who work for early childhood and elementary school.

Female labor force participation has been a substantial increase in female progress, especially in Middle Eastern European countries. Female economic revival took place for the first time in the Nordic countries, which experienced changes in the employment of 
woman with a new working pattern. Woman did not withdraw from the labor market after marriage or became mothers, but continued to be used until retirement age (Livia et al., 2014).

Indonesia is experiencing a process similar to developed countries in expanding female gender roles. Quoted from a gender-based human development book in 2017 in collaboration with the Ministry of Women's Empowerment and Child Protection with the Central Bureau of Statistics written by Rahmawati \& Lukitasari (2017), the article explains the increase of female gender roles in Indonesia. It is marked by the birth of great females, where they are able to show their role in the public sphere, have longer lifespan, and have opportunities to go to school as male. They have also professionalism in the world of work and their income is slightly much bigger. Purbalingga has dimensions similar to the dynamics of gender roles that place female in the opposite conditions as a result of rapid industrialization in areas that are still rural. Females have a greater acces to job opportunity, economic control, and access to banking services. Furthermore, they have an open network of friends, and ease in motorbike credit services.

The main problem in this article is that industries with a background in rural culture and agriculture cause a shift in gender roles. Females do not just carry out their domestic roles, but are the main pillars of breadwinners, dominate in the economy, control family assets, and have higher social status than their husbands. Males are not the main breadwinners because of minimal employment opportunities, and are more involved in the domestic sphere. This article focuses on finding an explanation of the changes in new gender relations and the vulnerability of men in women's labor protection policies.

\section{Methods}

This research uses mixed methods research. A combination of quantitative and qualitative research in various research processes (design, data collection, and data analysis) which is able to provide a better comprehensive and in-depth understanding of a social research problem (Putra, 2017). Mixed methods research in this study uses concurrent triangulation design, research that combines qualitative and quantitative research methods by mixing two methods equally. Through this research method, the results of the study will be more complete and objective because it uses triangulation data collection. Furthermore, qualitative and quantitative research methods are formulated in a concise step. The first step is to formulate both qualitative and quantitative issues in the research on the vulnerability of male in the protection of female workers. Quantitative problems with a survey approach through questionnaires distributed to industrial workers in the Purbalingga Regency area or industrial area. The second step in qualitative research is in accordance with the formulation of the same problem in different segments, namely the labor family. The focus of the problem is reviewed by interview guidelines. The guideline is used to interview in depth the pairs of workers and other workers. In accordance with the focus of the research and approach to the problems studied, the research subject were females laborers in the wig and eyelash industry. In addition, the subjects include females' labor husbands, families, community leaders, and religious leaders. Moreover in the broader scope, it involves the Manpower and Transmigration Office, the Social Service and Women's Empowerment, Development Planning Agency at Sub-National Level (Bappeda), Commission III of DPRD/ Regional House of People's Representatives, Religious Courts Office in Purbalingga Regency, and NGOs operating in labor cooperatives.

\section{Female worker and socio-economic changes in new industrial communities}

The role of female gender according to Chu \& Posner (2013) shows the new gender 
role that has entered the wider dimensions. The role of female begins with increasing new responsibilities of femail outside the home, and being paid workers. In addition, it covers the case of increasing the number of female in public office, advances in health, economic capacity and the ability of female to end gender discrimination in big companies. In 2014, data showed that the dominance of female in the field of professional labor, services, and marketing were in the proportion of $57.2 \%$ and $53.9 \%$ compared to male workers. The significant role of female in their new role is in the development of the creative economy industry. It shows the role of female as the main players with the involvement of female in the work of the creative economy reaching as many as $53.86 \%$. In the following year, in 2015 and 2016, females workers in the creative economy industry showed an increase from $38.11 \%$ in 2015 to $41.69 \%$ in $2016 .^{2}$

The gender role of female in the world of work has become a global phenomenon in the time of the economic crisis in a number of countries. It triggers the emergence of a new awareness that confirms that females are the most resilient in facing the crisis. This is because female workers have a careful, meticulous character, and are easy to adapt to the challenging global economic situation. This condition began to be realized by economic actors to employ female because it was more profitable in the world of work. ${ }^{3}$ At the family level, with the increasing public role of female, it is expected that the bargaining position in the presence of husbands will change, where the ability to finance herself is higher. The role of female working in the public sphere to help the family economy becomes a demand that the family's economic needs are

\footnotetext{
${ }^{2}$ https://databoks.katadata.co.id/datapublish/2018/09/21/ perempuan-indonesia-mendominasi-industri-ekonomikreatif

${ }^{3}$ Darwin, 2017 in the Kompas Daily, 31 March 2017, about gender mainstreaming has not provided optimal results).
}

met. Female as breadwinners have positive implications for a better family life (Irawati \& Hati, 2013). The role of female in helping the family economy is increasingly felt by increasing the family financial economy, fulfilling the needs of luxury goods, increasing living standards and improving family social status (Arsini, 2014). Female worker to bring about changes in the construction of equitable gender relations and gender equality will quickly be realized (Rofi'ah, 2015).

Purbalingga Regency as one of the regions in Indonesia that is open to investment, allows international scale companies to play their role in the business and export-based industries. One of them is the wig and eyelash industry, which has been developing its business since 2000 in the area. The existence of a wig and eyelash industry provides opportunities and chances for female to enter the world of paid work. It is the opportunities and chances to work for female that have an impact on the increasingly dynamic processes and dynamics of gender roles. The classic view on which female are placed in the domestic sphere is slowly experiencing a shift reaching the public world. The shift in this role is a pressure point in understanding the new gender role of female in Purbalingga Regency. LA, female workers in the wig eyelash industry, expressed one of the opinions and carries the following phenomena;

"The first thing that can be seen by the eyelash industry is the creation of a culture of unemployment and high productivity of female which is not followed by male. There are many opportunities for female to earn high family income, but this has the effect of decreasing the productivity of male, instead of not having jobs for male, but they are getting lazy."

Mas VL conveyed a long interesting thing in the other hand. He was a former laborer and labor cooperative activist who fostered workers 
to build cooperatives around the factory. The explanation is as follows;

"The interesting presence of industry in Purbalingga Regency is inferiority, superiority of female or whatever. Female are more confident in determining when to have sex. Wives determine the number of children, the color of the house, and decide to take a motorbike or not even in case of its in color. They are superior to all information, association, and socialites. Meanwhile, the husband sometimes looks insecure about feeling inferior. It can be seen from several things, more succumbing to his wife or the term like "husband is afraid of his wife". The husband is ashamed of his wife's friends so he rarely get along with others, and is afraid to disturb his wife's rest time when overtime at home."

Similarly, according to NA, the things seen and experienced by the Purbalingga community in the presence of the hair industry are as follows;

"The impact with the industry that is felt is the duty of mothers to be neglected to care for and educate children. So that it is clear that, the development of children in this area is a lot naughty. In addition, there is no chance for male to work. Female enter almost all jobs. For example, the job industry being a gas station official. Now, female are willing to work. It is the concerns to the younger generation, especially female who are no longer want to go to school. Junior high school education graduate has also been accepted in the world of work. This is what really makes us worried."

The statement shows the social construction that was built about female industrial workers in Purbalingga Regency. Female appear as different female, breadwinners, confidence, have a bargaining position with their husbands and relationships that are built between females workers that have not been seen so far. The discourse of female and industry in Purbalingga Regency has positive and negative implications for their lives. The positive perspective of the existence of industry is shown by the active role of the female population in economic, social, and political life that is getting better. Data on local government performance reports in 2015 showed a good thing. In 2011-2013, the gender development index in 2011 was 63.80, in 2012, it rose to 63.89 and in 2013, it rose to 64.88 . The next development was in 2016, the gender development index at the target $>64$, realized 90.13 , so that the achievements were $140.83 .{ }^{4}$

This condition is comparable to the achievements of gender development in Indonesia. In the 2017 gender-based human development book, it shows an encouraging thing for Indonesian females to increase their role and recognition of their existence as a counted part of development human resources. That case is indicated by the following; 1 ) the emergence of increasingly powerful great female who show evidence of gender equality, 2) the professionalism of female workers is increasingly taken into account. Female workers as professionals in 2016 was as many as $47,59 \%$. This achievement increased by 3.39 and this achievement was the highest in the period 2010-2016.3) The contribution of female in increasing income is growing, 4) The Gender Development Index shows evenly between the Regions of Western Indonesia and the Region of Eastern Indonesia. ${ }^{5}$

Considering from the income of female laborers based on a survey of 344 labor

\footnotetext{
${ }^{4}$ Government Performance Accountability Report (2014, p. 63) and Government Performance Accountability Report (2017, p. 52)

${ }^{5}$ A gender-based human development book in 2017, in collaboration with the Ministry of Women's Empowerment and Child Protection with the Central Statistics Agency
} 
Table 1.

Monthly earnings of female workers in Purbalingga Regency in the 2018

\begin{tabular}{clcccc}
\hline & Frequency & Percentage & Valid Percentage & $\begin{array}{c}\text { Cumulative } \\
\text { Percentage }\end{array}$ \\
\hline \multirow{6}{*}{ Valid } & $<1$ million & 69 & 21,9 & 21,9 & 21,9 \\
& $1-2$ millions & 223 & 70,8 & 70,8 & 92,7 \\
& $2-3$ millions & 21 & 6,7 & 6,7 & 99,4 \\
& $>3$ millions & 2 &, 6 &, 6 & 100,0 \\
& Total & 344 & 100,0 & 100,0 & \\
\hline
\end{tabular}

Source: Primary data that has been processed in 2018

respondents, an overview of the income of female workers in the wig and eyelashes industry was obtained according to groupings. When it is calculated per month, as many as 69 people or $20.1 \%$ will earn less than 1 million. Female workers who earn 1-2 million are as many as 241 people or $70.1 \%$. Female workers who earn between 2-3 million are as many as 29 people or $8.4 \%$, while those who earn more than 3 million are as many as 5 people or $1.5 \%$. Considering from the structure of income obtained by female workers, it can be seen in more detail in the following table 1.

The economic activities of female workers bring their own assessment to the public. It is stated by local and national media, which mention a number of things about women and industry in Purbalingga Regency. The opinions can be seen as follows; 1 ) the existence of industry changes the face of the economic system with female labor being the driving forces of the economy of the community not only in the city but also in the village. This is indicated by the better economic conditions of the village community. 2) Wig and eyelash industry in Purbalingga Regency provide more opportunities for female than male, where labor absorption is 58 thousand. Male workers fill only $10 \%$. 3) The emergence of discourse on the dominance of female is as a result of industrialization with the emergence of the term pamongpraja phenomenon of male changing roles carrying out domestic roles. ${ }^{6}$

\footnotetext{
${ }_{6}$ https://radarbanyumas.co.id/perusahaan-di-
}

Responses and opinions from both interviews and public opinion that developed in the community, the existence of laborers and industry has changed the pattern of life of female workers and their families. Female workers who initially as female who are considered as complementary in the family have an important role in the family economy. Even from some of them explained the importance of women having income. Female workers can help their husbands in fulfilling their needs, besides that, they become the foundation of the family as the main breadwinner.

The implications of the status of female who have jobs and wages, continue to create a public perspective. It assumes that Purbalingga female are those who are able to play more roles not only to be housewives who stand on their husbands' livelihood, but become female who can support themselves and their families to fulfill secondary needs. They can afford to buy a motorbike with a salary cut system from the workplace industry.

\section{The New Gender Role of Female and the Vulnerability of Labor Husbands in Socio- Economy}

The vulnerability referred to in this article is the difference in access and control of resources. Access and control of resources is needed by individuals to obtain a decent life. It is also defined as a situation where groups

kabupaten-purbalingga-hanya-tertarik-merekrutpekerja-perempuan/ 
of people do not have adequate strategies and resources to avoid a number of risks of what might happen from an activity. Gender vulnerability does not originate from a single factor, such as poverty, but reflects a pattern of historically and culturally specific relationships in social, cultural, and personal life institutions. Vulnerability is more in contact with economic, racial, and other inequalities. This relationship creates dangerous social conditions that place certain groups at different risks (Ashraf, \& Md. Abul Kalam Azad, 2015).

This vulnerability arises from the transition of females' private roles to the public. The new roles of female become important. They act as the main component as a driver of development both the central and regional levels. Females also determine the needs of labor and the economic system. Gender portraits in Indonesia, as a whole, based on the comparison of Indonesia's population in 2015 is about 255.5 million people. Almost half or exactly $49.75 \%$ are female residents. Female potential is explained as follows:

"The potential role of female in the development is very huge and can be a significant contributor to economic development. Female can play a role in economic development through active participation in the business world. Female participation in economic development is not only to improve household welfare and reduce poverty but is also a solid foundation in other sectors." ${ }^{7}$

Along with the movement of feminism, global change, and trans-international trade, female experience a process of transforming roles into a central role in the dynamics of patriarchal society, not only in modern society but also in the third world community. The

Gender Statistics Portrait of Gender Inequality in the Collaborative Economy of the Ministry of Women's Empowerment and Child Protection with the 2016 Central Bureau of Statistics, p. 67-68 key domains of social life and relationships between individuals, offspring and matrilineal inheritance, matrilocal dwellings, marital practices, and social identity are determined through female ancestors, and cultural symbols rooted in motherhood. The description of females' visualization and the sources of economic status are determined by them. Community culture that emphasizes matrilineal power shows the relations between male and female to complement each other, which are carried out through consensus, coexistence, and compromise. The worldview requires cooperation and care as a basic principle of community rather than seeking control or dominance. The result is a picture of a seemingly beautiful community, free from structural inequalities and power struggles that are visible and often regarded as basic human characteristics in people's lives.

Rational reasons and shifting development strategies as well as increasing gender politics require female to play their part in the gender construction outlook. Likewise with Purbalingga Regency, area that is currently more famous for its industrial area, especially wig and eyelashes, has an interesting side about the lives of female workers. This becomes interesting because female laborers in Purbalingga Regency are a long-standing phenomenon, in rural areas and agriculture with a patriarchal culture that is still strong and entrenched.

The process and dynamics of changes in gender roles in industrial societies in Purbalingga Regency are the other side of female lives, which are described along with the new role of female that has occurred in the world especially in America, Africa, and even Asia. Various factors have influenced these changes, from education, globalization, economic crisis, and the strong willingness of female to become male partners who have equal positions in various fields of life. Based on the reasons for the results of the study and 
the rational reasons for the new role of female and their implications, the following lays the explanation about the new role of female in the labor family in Purbalingga Regency. Based on field notes and observations of informants who were met at the time of the interview with both the husband and his wife, there were obtained as follows;

"That afternoon a husband of a worker named Mas HE, aged 32, had just delivered a doctor's certificate stating that his wife was sick so she did not go to work. His wife is a laborer named FB who is 24 years old. She has been working for more than 4 years since 2012. Mas HE and MBA FB are families with one child who already has his own family life by occupying his own home, which is located at Karang Gintung RT 1 RW 1 Sumbang Banyumas. His wife works as a laborer who earns between 2,500,000-2,900,000 IDR. Her husband works as a traveling baker earning between 100,000, per day. In managing the household, who could, he/she do except cooking because he did not cook. The thing to take care of her child was handed over to her grandmother. The wife leaves for work from 5 to $7 . "$

Pak US and Pak JU conveyed another explanation about female factory workers. It is stated as follows;

"If the wife is at work, the husband is unemployed. Yes, sometimes the children are sent to their father-inlaw, sometimes her husband takes care of the children. If her husband is unemployed, his wife works most of his household in disarray, which leads to divorce. The reason is economic factors, maybe his wife at work gets income, and her husband is odd. Poor children!!. What's more, nowadays, his wife holds her cell phone, and her husband is jealous. If a husband works, his wife does not have family problems. "There are negatives; there are positives in the efforts of seeking for a job. Only here, there are many positives, because there are many workers, like from Purwokerto, Banjarnegara, Banyumas who pick up a lot. Social status increases because of working. Those who work with motorbikes will increase their social status. Sometimes in one home two people are working at one firm, and they have two motorcycles in their home."

The results of observations and indepth interviews with workers and industry stakeholders show that female are potential staff and play a central role in family, social and community life. Female have accessibility and the opportunity to work in the public sector. They will have the regular wages and income, social status, the opportunity to socialize with a wider scope. They tend to open themselves to information with the ease of possessing communication tools obtained from their work.

The change in gender roles becomes discourse about female who are constantly changing according to the development of gender discourse. In the beginning, it was known as the classic view which mentions female as weak creatures compared to male because of gender inequality, marginalization, subordination, stereotype, and violence. The next development is a discourse about gender discourse and feminism. This issue is a movement to fight for female from injustice, emerging movements of liberal feminism, radical feminism, Marxist feminism, and feminist socialism. Next is the emergence of female discourse in the era of globalization and international trade. The role of female is increasingly strong and determines the family dynamics. They can act as motivators, auditors, managers, and at the same time, they can allocate income and be strategic family stakeholders. 
The new role of female has a direct impact on the families that have a direct impact on the distribution of domestic and public gender roles, economic contributions in the family, increased welfare and respect for couples in the family. Economic contribution is the dominant factor in family dynamics for collaborative partners between husband and wife who are increasingly aware of their roles and responsibilities.

Family dynamics in view obtained from theoretical studies states that income is an important element in influencing family patterns in interacting and respecting husband and wife partners. In accordance with the results of observations and observations on the workers' families, it is found the following description:

"Mr. RS is a 38-year-old family head who has 1 (one) wife named Mrs. EK who works as an industrial laborer at PT Midas, Purbalingga Regency. His wife is an industrial worker who worked since 2014. Initially he was a housewife who was active in the house. Over time and opportunity, the industry opens opportunities for female to work as laborers. With reluctance, finally the husband allowed. Since his wife worked, the family dynamics have also changed indirectly. The family has two children, one is in $2^{\text {nd }}$ grade of high school, and the other one is in second grade at elementary school. There are things that change especially in nurturing and educating where children are no longer with their mothers, but handed over to their grandmothers or parents of the husband. Domestic roles are not borne by husband or wife but together. The wife is more for her own needs and has social activities with her friends."

The new role of female is the other side in reviewing gender issues, which are always faced with the situation of female who suffer, discriminate, dehumanize, and segregated by humans. The importance of discourse on female achievements in all fields including politics, social, economy and culture is well noticed. Different female studies become a developing perspective for them in influencing the community by proving that they are able to play an active role in community as males do. This is what can be understood that female new role becomes a fundamental driver and change in the process of social change. The simple implications rest upon in female as workers, main breadwinners and economically independent in terms of family context.

The role of tradition or domestic role is considered as the role of mother, namely the role of woman as wives, mothers, and regulators of household management. The traditional role of female arises and develops as a social product of community, meaning that how much a female performs a role in a household varies according to place, time of culture, and customs in a new industrial community. The industry of wig and eyelashes has implications for family dynamics that can be observed according to the results of interviews and observations in the field. The results are as follows; first, the tendency of female who work to delay having children. Even if they already have children, it is another problem. The problem is that who will care for children during their time of working. The habit that is carried out by workers is entrusting children to their parents or the final choice is with their husbands if they do not work permanently. Second, the economic contribution given by the wife after working is an important part of family sustainability. For workers whose husbands work, it is not a crucial issue as in the families described in the in-depth interview. This is different from female workers who work while their husbands do not work. They have to fulfill basic needs even to finance her husband's pleasure. Third, the pattern of family structures that become the heads of female families is increasing. This is in 
accordance with the general description of the higher level of divorce in Purbalingga Regency.

In accordance with the results of interviews, observations, and theoretical studies, female workers with new roles in the public sphere as workers conclude several things. The conclusion is that female workers in the wig and eyelash industry are a form of change in gender roles caused by global changes with the presence of foreign direct investment (PMA) to the regions on a large scale. Labor segmentation that requires female makes them to have an open opportunity to work in the public sphere. The economic contribution in the family to the labor family has an important role in increasing family income. Contributions also play a role in the improving family economy with the opportunity to spend on basic and other needs. Besides, they have the opportunity to have luxury items bought by them. They have chance to buy the motorbike for their own sake in case of transportation.

Family dynamics clearly change as the division of roles between female and male in the labor family. Female will be free to determine their lives as partners with their husbands. The positive implication is that females' bargaining position in family dynamics is increasingly valued. Likewise socially, female have wider accessibility compared to male in obtaining employment information. In the end, in family life, awareness about gender roles needs to be carried out properly.

\section{Welfare State Response in Practical and Strategic Policies for Women's Labor Protection}

Men and women do not play different roles in community. With different levels of control over resources, often both of them have different needs. Description of gender interests according to gender needs, identification of important differences between practical and strategic gender needs, is the first step for the state to respond effectively. It is done so in order to control the practical and strategic needs of the impact of changing female gender roles. State's actions are carried out through family policies related to domestic violence, reproductive rights, legal status, and state policies regarding welfare. The state in carrying out its intervention is a challenge in the policies implemented to maintain the balance of roles that women and men normally play in the household or in the community. The state in its intervention does not disturb the traditional balance between power and authority between men and women. The state guarantees the needs associated with activities that keep households running and the daily survival of the family to function. This framework understands practical needs in the dimensions of three roles that have been carried out by female. Females' gender roles in the public sphere with incomegenerating activities, is sometimes done by them at home. It is actually based on practical household tasks such as cooking and sewing, and carried out in parallel with women's household responsibilities (Moser, 2012).

Analyzing the practical needs of female laborers is being revived with the role of state welfare. State faces different challenges in the future, and the possibility of responding and taking different policies. One of the main challenges of welfare state is the dynamics changes that continue to be different. The state not only faces challenging globalization, but social problems that continue to change without being able to understand the causes. Therefore, the approach to welfare state is often monotonous by increasing competitiveness, prioritizing social investment, especially education, and innovation. In addition, new social challenges can emerge and need to be solved with new strategies and ways (Andersen, 2012).

One of the new challenges of the welfare state is the paradigm of the study of woman as new female with new gender roles that have been played. So far, gender studies still assume the traditional gender norms 
that mention female as second-class sexes. Nowadays studies are developing which are in contrast to approaches to female who appear differently as autonomous female. Male are not only as breadwinners but also as play a role in households as unpaid workers. Male experience repositioning roles with female for certain reasons. They are in case of economic crisis, illness and various other reasons. This is what needs to be explored differently. One of them is the study of female workers who have broad opportunities compared to male. The existence of male is not as in general, experiencing limitations in the accessibility of work, which results in social change, both for the workers' families and the community.

Therefore, the dynamics changes in dynamic gender relations and the state's response in addressing, formulating, and implementing policies that are in line with the problems faced in new industrial societies in Purbalingga Regency are discussed. So far, the state is considered only as an institution capable of providing social services to overcome various social problems. Meanwhile, in the context of the labor community, there is a relationship between the state, the labor family, and the industry. This is referred to as the welfare triangle approach in the welfare state. Private domains that have been played by female workers have shifted towards a more open public domain role. The shifting of gender roles has implications for social configuration at the family and social level. Female become central and work as professional workers along with increasing education and openness in thinking and creativity. In addition, female have wider accessibility in terms of economy with increased income and a position that is trusted and placed as a more managerial and decision-making workforce.

Current gender studies understanding experiences dynamic development with discourses that are more interesting and different perspectives, where female in the millennial generation become a broader new perspective in understanding the role of female in the era of information and technology. Female have open opportunities in all areas of life, and experience a shift in the recognized role of female in terms of abilities and skills. The difference is that male, who are able to play a role in domesticization in family life, making them no longer awkward in caring for and nurturing their children. New male are figures who are able to understand and know gender roles without discrimination. Opportunities and awareness are a new era in a world that is more equitable and appreciates gender roles. ${ }^{8}$

The existence of a wig and eyelash industry up to the corners of the village with a plasma system provides new hope for a decent life in the community especially female. Females start a new realm as workers who earn income and public activities that are different from the former. This change has influenced the mindset to a certain extent. In the previous time, they are considered as unpaid domestic workers, and now they are no longer a complementary sex but rather an important role in both family and social .

The shifting females role in the public sphere is an encouragement for them to be different part of the human resources in Purbalingga Regency which is able to contribute to the progress of the region. The appearance of female as workers indirectly affects family income and influences the structure of the regional economy. At the labor level, the existence of industry is a symbol of change for the role of female who are one step ahead. One significant change is the willingness and ability of them to work in various fields of expertise.

Based on the perspective and reality of female new gender roles, female public roles

\footnotetext{
${ }^{8}$ Partini, 2017, Changes in the Role of Women: Opportunities and Challenges, Professor's inaugural speech at the Senate Hall of Universitas Gadjah Mada, 10 October 2017, Yogyakarta
} 
are increasingly recognized at international, national, and local levels. At the local level, they do not only work for industrial workers, but also work in other private roles. Their ability in the public domain is undoubtedly a part of being taken into account in the development in Purbalinga Regency.

The shift in the public role of female and the birth of the great woman, who have been mentioned, proves that the steps of gender development in realizing gender equality are increasingly appearing. Likewise, the dynamics of gender relations in the family signify a new era in new gender roles. Males experience the domestication of roles that are not always appearing masculine, manly, macho, and super hero. However, they are able to take on domestic roles by taking responsibility in caring for and nurturing the children.

However, the issue of gender development is also increasingly complex. This was marked by the gender inequality in the family, the lack of regulations that emphasized issues of gender inequality in the family, the low level of state initiation, and the central and regional governments to respond to the implications of changes in gender roles that occur within the family. This is where the joint role is demanded to put the family institution as the beginning in gender development, because the family is the most basic institution and has a function in instilling equality values and gender justice.

It goes on the same problem in the families of female workers in Purbalingga Regency. Potential problems still have not been well resolved. A problem of female and industry is a map of the real problems that occur in the field, especially those related to the domestic life of the workers' families. This needs to be well known to understand the real issue of gender roles. When female public roles increase, social problems will follow.

The thoughts of DPRD members of Commission III, which are in charge of the development and empowerment and protection of female and children, in the FGD event, were looking for solutions to industrial impacts for children. This was held on May 23, 2018 in the Parliament Building in Purbalingga Regency. In the FGD, DPRD members and stakeholders expressed various opinions for children from the Health Service, health workers, the legal department, and academics. One of the opinions came from DPRD Commission III, Mrs. SM. She argued as follows:

"So far, the attention of the regional government to the existence of the industry is still minimal, especially regarding the fate of the children of industrial workers. The solution of the regional government to overcome the problem has not found. Indeed, so far, the local government has tried to anticipate the problem of the negative impact of the industry by initiating the realization of Purbalingga as a child-worthy city. Nevertheless, the government has not seriously implemented this as, and as a result, Purbalingga is still an emergency in child problems."

Another member of Commission III of the Regional Parliament of Purbalingga, namely $\mathrm{Mr}$. $\mathrm{CH}$, also conveyed another opinion. He argued that:

"Industry causes a wide impact on the lives of workers' families, one of which is the problem of their children. Mothers who work as labor is also problematic. Even though their father or grandmother cares for the children, it does not solve the problem. Therefore, it is necessary for the regional government to be responsible for supporting the welfare of children, providing training to pre-marital couples because based on existing data, $90 \%$ of pre-marital couples do not have the provision of educating children." 
Mr. YB from the Purbalingga Regency Health Office also conveyed similar views. He stated the following:

"Investment and hair industry have an effect on changes in child development in Purbalingga Regency. This problem is a series of interrelated problems. Many workers do not pay attention to children's growth. Consequently, it leads to promiscuity. The marriage dispensation begins, more divorce claims. The result is that grandparents will be caring for the children. The other problem involves the lost generation problem, breastfeeding and other crucial problems."

Industry at least provides color in the lives of the people of Purbalingga Regency as a new industrial area that has the potential to accelerate development and pursue various underdevelopments. But the thing that needs to be anticipated is the various problems that have been explained by several informants. In addition to the problems that have been mentioned, the following are the potential problems that are crucial for female and industry workers in Purbalingga Regency that need to be handled by the local government properly.

There are family problems in the industrial community in Purbalingga Regency. The problems identified are dominated by the existence of social economics problems such as divorce, family member conflict, poverty, domestic violence, and juvenile delinquency. At this time, the crucial problems that has not been handled properly are as follows:

1. Purbalingga Regency is experiencing severe malnutrition, which is quite high. At the Central Java level, it is in the seventh position. This indicates that Purbalingga area still faces poverty. In addition to malnutrition, the number of poor people spread throughout Purbalingga Regency is 176,040 or $19.75 \%$ of the total population in the area. Poverty is also followed by other problems related to uninhabitable homes, as well as food problems or consumption levels, which are still low.

2. The spread of deadly diseases are considered a time bomb because they are not known as a whole. HIV AIDS sufferers continue to increase in number.

3. Juvenile delinquency and promiscuity increase due to children' unwell maintained. Working mother factors are even unresolved. ${ }^{9}$

Besides that, the problem that needs to be taken seriously in accordance with observations and secondary data is the problem with the high divorce case in Purbalingga Regency. In 2016, 562 cases were entered, while 522 cases were dropped and 20 cases were left. In 2016, as many as 1682 cases were entered, 1633 cases were dropped out, and remained 49 cases. The cases of marriage dispensation in 2016 were 126 cases, 118 cases were sent in, and remained 8 cases. The high divorce among the community is one of the reasons for economic problems, which are the reason for divorce. The employment status that filed for divorce in September 2016 was a labor profession with a quantitative number reaching $36 \%$ of the number of divorce cases in Purbalingga Regency.

The profile of divorce in Purbalingga Regency in 2015 based on the number of cases decided by the Purbalingga Religious Court in 2015 were 1,398 cases. Most of these cases are in the form of divorce, which are as many as 882 cases $(63.09 \%)$. The rest $(36.91 \%)$ is divorce divorce. The dominance of the plaintiffs from among the wives shows that the phenomenon of divorce in Purbalingga Regency is in line with the phenomenon that occurred in Central Java and Indonesia, even with a higher percentage level. ${ }^{10}$

\footnotetext{
${ }^{9}$ Purbalingga Regency Regional Medium-Term Development Plan (RPJMD) 2016-2021 CHAPTER IV, pp. 4-5.

${ }^{10}$ The results of in-depth interviews with employees of the
} 
Based on data from 2015 and 2016, divorce in Purbalingga Regency is continued to increase. The cause of the problem is not known. Based on the records of the Purbalingga Regency religious court, the reason for the divorce application is the economy. After being examined more deeply, not only in economic matters, even divorce among nonlabor professionals has increased. There must be pre-marital education, besides that, mutual awareness between couples needs to be built to create a harmonious family. The following shows divorce data, which always increases every year. One example is the data in 2015:

Table 2.

Types of Divorce Cases in Purbalingga Regency in 2015

\begin{tabular}{lcc}
\hline Type of cases & Total & Percentage \\
\hline Divorce & 882 & 63.09 \\
Revocable divorce & 516 & 36.91 \\
Total & 1398 & 100 \\
\hline
\end{tabular}

Source: Purbalingga Religious Court, 2015

Identifying these various problems is a shared responsibility, especially the Purbalingga Regency government to deal with the problem. What the source of the problem is, what the need is, the strategy, and how the program is developed to address the public problem should be settled down. The problems that occur in Purbalingga Regency show that changing social structures due to social configurations shift female gender roles from domestic to public. These changes include perspectives on the role of female to not always be at home. There is a shared obligation to earn a living. Family economic income tends to be higher $60 \%$ for female compared to male. The ability to earn a living and earn more income than male results in the relationship of husband and wife changing. These changes are mainly from the aspect of mastering economic assets

Religious Courts and the processing of secondary data at the Purbalingga Regency Religious Courts in 2017. and authority in decision making at the family level.

How the state faces problems such as the dynamics of the life of workers' families becomes complex jobs. Like the challenges of welfare state that is open, each state will differ from one state to another. Countries with a social democratic system like the Scandinavian will deal with it differently. Besides the problem, there is also different treatment for developed countries in advanced industrial societies. The problem may be in case of demographics, fertility, and an aging age of work. Compared to the third world state, it will be different. Therefore (Costa, 2014) in assessing the welfare state, the problem must be contextualized. One of which is the problem of the workers. In this context, the problem of problem identification is actually a part of planning in solving labor problems. In addition to the perspective of the welfare triangle, which involves the state, industry, and workers 'families, it is necessary to explore the extent to which the company cares about the fate of workers from the emergence of new gender relations among the workers' families.

The strategic needs of female are generally related to overcoming problems related to gender laws and contracts that tend to be biased towards female. The context of the female labor community is often confronted with the issue of the status of female with divorce, violence, abandoned wives, and economic losses problem. Therefore, the strategic need is to improve the status of female, through regional regulations that give female and male equal rights, law enforcement, and establish rights to land and other property. Other strategic needs for female can include local laws/regulations on inheritance so that female has the same rights as male. In the industrial community of Purbalingga Regency, women who earn income through companies are proven to increase their status, accompanied by a greater influence in decision making and control of resources, in their families and communities 
Strategic interests are related to female who change their in community and who help to get more equality with male, and change gender relations. In this context, the presence of the wig and eyelash industry has positive implications for female with more open accessibility. The opportunity to get jobs is increasingly clear. Female with an increase in their public role indirectly provide space for thinking to be independent. This industrialization is able to change the face of female in Purbalingga Regency. In addition, the existence of the industry reduces the number of unemployed, and welfare increases because female workers earn income. However, new problems arise. The increase in the welfare of female workers is not balanced with the handling of problems in the workers' families. These problems include; a gap between high employment of female and male, childcare, family disharmony, and violence.

Starting from these problems, there needs such strategies to solve the problems of female workers and their families in new industrial communities. In accordance with observations in the field, the state, industry, and community have a responsibility and joint commitment to overcome the problem. The main problem with the impact of industrialization is the problem of children as the next generation in Purbalingga Regency. Realizing this state, the local government has made steps to respond appropriately. The steps are to formulate legislation that regulates the issue of female rights, as well as eliminates discrimination, and eliminates domestic violence. In addition, the regulation involves legal protection for victims of domestic violence, and legislation compiled with a perspective of gender equality. Moreover, it is necessary to formulate local regulations that favor female and children in the form of Child Friendly Region Regulations (KLA) and family care policies that develop community-based childcare facilities.

\section{Conclusion}

Traditional gender norms in the new industrial community, which state that female are subordinated and men dominate, do not always occur even though they have only secondary education level or lower. Female labors from data analysis are able to act as social skills workers. Female workers with an income earn in the industry feel exploited because wages are often incompatible with standards, or inadequate industry attention with poor service. However, female appears as economic inspirations of families and female in the environment. They do so by employing the other female and building networks between industries and activities community economy in the form of plasma. This is what distinguishes female workers with their social abilities. They are initiatives, open and independent.

Labor female with the social skills and business networks that are built between modern industry and home-based businesses with plasma systems become part of female with new independent roles. They can control economic assets, inspire communities, and be saviors of the family. These important parts were not much revealed in previous research. Labor females are able to appear in the worker's family by developing a business that involves her husband or partner. Female with a new gender role can be seen from the values that require traditional gender norms not to be rigid. Meanwhile, male replacing the role of wives in the domestic sphere into a consciousness have not been well developed. So, the role of male who deliver their wives to work, care for and accompany their children is seen as male who are exploited as pamongpraja. Gender awareness in this case has not yet emerged and has resulted in role conflict with higher divorce claims. It moreover includes neglecting child problems and the absence of representative childcare needs. In addition, industry awareness for the lactation space is 
still lack as well as community parenting that has not built.

The country's response to changes in gender relations in new industrial societies from the aspect of identifying the problems and needs of female workers has not shown the right analysts. It still uses the classical paradigm with traditional gender norms. The state has not been able to respond to the actual gender problems with the development of the problem and the role of gender is constantly changing. The state uses a top down approach in formulating policies to initiate actions by formulating regulations that can regulate and resolve problems. The main problems are related to childcare, exclusive breastfeeding and accompanying children. Those problems have no systematic solution from the state. Policy formulations on handling genderbased violence and children cannot resolve family solutions and harmonization that is characterized by high divorce claims.

\section{References}

Andersen, J. G. (2012). Welfare States and Welfare State Theory. Aalborg: Centre for Comparative Welfare Studies, Institut for economi, Politic og Forvaltning, Aalborg Universitet. CCWS Working Paper.

Anonim. (2018). Indonesian Women Dominate the Creative Economy Industry. Retrieved November 20, 2018 from https://databoks. katadata.co.id/datapublish/2018/09/21/ perempuan-indonesia-mendominasiindustri-ekonomi-kreatif.

Arsini. (2104). Peran ganda perempuan pada keluarga masyarakat agraris: kasus 10 istri buruh tani di desa Putat Purwodadi Grobogan. Sawwa: Jurnal Studi Gender dan Anak, 10(1), 1-20.

Ashraf, Mirza Ali \& Md. Abul Kalam Azad, Gender Issues in Disaster: Understanding the Relationships of Vulnerability, Preparedness and Capacity, Environment and Ecology Research 3(5): 136-142, 2015 http://www.hrpub.org DOI: 10.13189/ eer.2015.030504.

Chu, A., \& Posner, C. (2013). The State of women in America: A 50-State analysis of how women are faring across the nation. Retrieved June 26, 2018 from https://www. americanprogress.org/issues/women/ reports/2013/09/25/74836/the-state-ofwomen-in-america/

Costa, E., \& Cesnova. (2014). The Welfare State and Gender Equality: Work-family reconciliation policies in Southern Europe. Paper prepared for presentation at the Conference ECPR Graduate Conference Innsbruck, 3-5 July 2014, p. 1-38.

Darwin. (2017). Gender mainstreaming has not provided optimal results. Retrieved from in the Kompas Daily.

Habibi, M., \& Buchori, I. (2013). Model spasial kerentanan sosial ekonomi dan kelembagaan terhadap bencana gunung Merapi. Jurnal Teknik PWK, 2(1).

Irawati, R., \& Hati, S. W. (2013). Motivasi kerja wanita terhadap kondisi sosial ekonomi di sektor perikanan. Jejak, 6(1), 93-105. doi: 10.15294/jejak.v6i1.3751.

Moser, C. O. N. (2012). Gender planning and development: Theory, practice and training. London: Routledge. doi: 10.4324/9780203411940.

Livia Sz, O., Richter, R., \& Kotowska, I. E. (2014). Changing families and sustainable societies: Policy contexts and diversity over the life course and across generations Changing families and sustainable societies: milies And Societies (Working Paper Series).

Partini. (2017, October 10). Changes in the role of women: Opportunities and challenges. Speech presented at Professor's Inaugural Speech in the Senate Hall of Universitas Gadjah Mada, Yogyakarta.

Purbalingga Regency Regional Medium-Term Development Plan (RPJMD) 2016-2021 CHAPTER IV, pp. 4-5. 
Putra, M. F. P. (2017). Mixed methods: Pengantar dalam penelitian olahraga. Jurnal Pembelajaran Olahraga, 3(1), 11-28.

Rahmawati, D. N., \& Lukitasari, I. (2017). Pembangunan manusia berbasis gender 2017. Jakarta: Collaboration Kementerian Pemberdayan Perempuan dan Perlindungan Anak with Badan Pusat Satistik.

Republika Daily (2018). Purbalingga Industrial Economy Women Workers and Radar Banyumas Daily, 6 August 2016 Companies in Purbalingga Regency Only Interested in Recruiting Female Workers. Retrieved from https://radarbanyumas.co.id/perusahaandi-kabupaten-purbalingga-hanya-tertarikmerekrut-pekerja-perempuan/

Rofi'ah, S. (2015). Membangun pola relasi gender berbasis kesetaraan dan keadilan gender. Jurnal Muwazah, 7(2), 93-107.

Rosin, H. (2012). The end of men and the rise of women. New York, USA: Penguin Group.

Singh, R. (2014). Status of women in today's society. International Journal of Humanities and Social Science Invention, 3(2), 59-62.

Vitali, A., \& Mendola, D. (2014). Women as main earners in Europe. ESRC Centre for Population Change WP , 56, 1-40. 